\title{
Review Penyediaan Sistem Informasi Menejemen Pegawai Pada Badan Kepegawaian Dan Pengembangan Sumber Daya Manusia Kota Pekanbaru Dalam Mendukung Kebijakan E-Government Pada Tahun 2019 \\ Oleh:
}

\author{
${ }^{1}$ Ramlan Darmansyah, ${ }^{2}$ Tito Handoko, ${ }^{3}$ Mohammad Yohamzy Tiyas Tinov \\ 1,2,3 Jurusan Ilmu Pemerintahan, Fakultas Ilmu Sosial dan Ilmu Politik, Universitas Riau \\ Email: 1․amlandarmansyah0367@student.unri.ac.id, ${ }^{2}$ tito.handoko@lecturer.unri.ac.id, \\ 3tiyas.tinov@lecturer.unri.ac.id
}

\begin{abstract}
Abstrak
Kebijakan E-Government adalah untuk mengurangi penggunaan sistem manual atau penggunaan kertas dalam layanan apapun. Adanya kebijakan teknologi informasi dalam lingkungan pemerintah diharapkan dapat mewujudkan e-Government yang transparan dan efisien. Tujuan dari penelitian ini adalah 1). Untuk mengetahui penyediaan sistem informasi manajemen Officer pada personil badan dan pengembangan sumber daya manusia Pekanbaru dalam mendukung kebijakan e-Government pada tahun 2019 dan 2.) Mengetahui faktor pendukung yang memberikan informasi kepada petugas manajemen sistem pada badan personalia dan pengembangan sumber daya manusia Pekanbaru City dalam mendukung kebijakan eGovernment pada tahun 2019. Metode yang digunakan dalam studi ini menggunakan pendekatan kualitatif, jenis penelitian adalah studi literatur di mana sumber data yang Diperoleh dari produk hukum, jurnal artikel, dokumen terkait dan sumber media massa. Penelitian dilakukan pada badan personalia dan pengembangan SDM. Hasil dari penelitian ini adalah penerapan program manajemen sistem informasi yang diimplementasikan oleh badan personalia dan pengembangan sumber daya manusia selain mewujudkan pemerintah berbasis e-Government juga mendukung kebijakan Walikota Pekanbaru. Adanya dukungan e-Government dalam penyediaan sistem informasi manajemen staff di badan personalia dan pengembangan sumber daya manusia Pekanbaru City.
\end{abstract}

Kata Kunci: Kebijakan; E-Government, Sistem Informasi Manajemen, Sumber Daya Manusia

\begin{abstract}
E-Government policy is to reduce the use of manual systems or the use of paper in any service. The existence of information technology policy in the government environment is expected to realize the egovernment is transparent and efficient. The purpose of this research is 1). To know the provision of Officer management information system on personnel Agency and Human resources development Pekanbaru in support of e-government policy in years 2019 and 2.) To know the supporting factors providing information Systems Management officer on personnel agency and Human resource development Pekanbaru City in support of e-government policy in year 2019. The method used in this study uses a qualitative approach, this type of research is the study of literature where data sources are obtained from legal products, journal articles, related documents and mass media sources. Research is conducted on personnel agency and Human resources development. The result of this research is the application of Program management Information system officers implemented by the Agency of personnel and human resources development is in addition to realizing the government-based e-Government also supports the policy of Pekanbaru mayor. The existence of e-government support in providing application of staff management information system at personnel agency and Human resources Development Pekanbaru City.
\end{abstract}

Key Word: Policy, E-Government, Management Information System, Human Resources 


\section{REVIEW PENYEDIAAN SISTEM INFORMASI MENEJEMEN PEGAWAI PADA BADAN KEPEGAWAIAN DAN PENGEMBANGAN SUMBER DAYA MANUSIA KOTA PEKANBARU DALAM MENDUKUNG KEBIJAKAN E-GOVERNMENT PADA TAHUN 2019}

\section{PENDAHULUAN}

Pemerintah harus memiliki komitmen untuk meningkatkan tata kelola pemerintahan yang baik, komitmen tersebut dapat dilihat dalam sebuah kebijakan maupun program yang dijalankan sehingga wacana untuk mereformasi birokrasi untuk menjadi tata kelola pemerintahan yang baik tersebut dapat terpenuhi. Agar ini dapat dimplementasikan maka dibutuhkan kebijakan Menurut Ealau dan Pewitt;(1973) dalam (Sore. B, Unddin \& Sobirin, 2017) mendifinisikan bahwa kebijakan adalah sebuah ketetapan yang berlaku, dicirikan oleh prilaku yang konsisten dan berulang, baik dari yang membuat maupaun yang melaksanakan kebijakan tersebut. Kebijakan merupakan tindakan dan keputusan pemerintah, kebijakan tersebut dicirikan dengan kekuasaan yang didominasi oleh pemerintah dan sesuai hukum serta wewenang pemerintah. Selanjutnya (Agustino, 2016) menjelaskan bahwa Policy decisions atau putusan kebijakan adalah putusan yang dibuat oleh pejabat publik yang memerintahkan untuk memberi arahan pada kegiatan-kegiatan kebijakan. Yang termasuk didalamnya adalah: keputusan untuk mengeluarkan ketetapan, mengeluarkan atau mengumumkan perintah eksekutif, mengumunkan aturan administrative atau membuat interpretasi hukum yang penting.

Bentuk kebijakan dalam kajian (Haryono, 2017) tentang kebijakan sistem aplikasi pelayanan kepegawaian bahwa dalam rangka mewujudkan e-government dilingkungan pemerintah terdapat beberapa masalah yaitu dalam dalam sinkronisasi database kepada sistem on-line salah satunya adalah tertundanya proses input data. (Richardus Eko Indrajit, Dudy Rudianto, \& Akbar Zainuddin, 2005) menjelaskan bahwa e-government sebenarnya adalah suatu usaha penciptaan suasana penyelenggaraan pemerintahan yang sesuai dengan obyektif bersama dari sejumlah komunitas yang berkepentingan. Ada beberapa faktor penentu tingkat kesiapan daerah untuk menerapkan e-government yaitu:

1. Infrastruktur Telekomunikasi yaitu pelaksanaan perangkat keras seperti komputer, jaringan, dan infrastruktur akan menjadi faktor teramat sangat penting dalam penerapan e-government. 
2. Tingkat Koneksi dan Penggunaan TI oleh Pemerintah yaitu sejauh mana pemerintah saat ini telah memanfaatkan beraneka ragam teknologi informasi dalam membantu kegiatan sehari-hari akan tampak sejauh mana kesiapan mereka untuk menerapkan konsep e-government.

3. Kesiapan Sumber Daya Manusia di Pemerintah yaitu pemain utama atau subyek didalam inisiatif e-government pada dasarnya adalah manusia yang bekerja di lembaga pemerintahan.

4. Ketersediaan Dana dan Anggaran yaitu sumber daya finansial untuk membiayai.

5. Perangkat Hukum yaitu pemerintah harus memiliki perangkat hukum yang menjamin terciptanya mekanisme e-government yang kondusif.

6. Perrubahan paradigm yaitu proyek change management yang membutuhkan adanya keinginan untuk mengubah paradigm dan cara berpikir.

Pada penegertian lain (Yudho Giri Suhcayo \& dkk, 2013) menjelaskan bahwa istilah e-government merupakan pendekatan dari electronic-government yang dapat diterjemahkan secara hafiah menjadi pemerintahan secara elektronik. Istilah ini diasosiasikan sebagai pemanfaatan TIK secara maksimal untuk meningkatkan efektifitas, kinerja, dan pelayanan pemerintah bagi masyarakat umum. Menurut (Indrajit;2002) dalam (Vita Elysa \& dkk, 2017) setidaknya terdapat empat klasifikasi hubungan bentuk baru bagi penggunaan teknologi informasi dan komunikasi pada egovernment:

\section{Government to Citizens}

Yaitu aplikasi e-government yang paling umum dimana pemerintah membangun dan menerapkan berbagai portofolio teknologi infornasi untuk berinteraksi dengan masyarakat.

2. Government to Business

Bentuk penyediaan pelayanan informasi bagi kalangan bisnis. Semacam perusahaan swasta membutuhkan data dan informasi dari pemerintah.

3. Governement to Government

Aplikasi e-government yang dalam bentuk berinteraksi antara satu pemerintah dengan pemerintah lainnya untuk mempelancar kerja sama.

4. Government to Employees 
Japs: Jurnal Administrasi Politik dan Sosial, Vol. 1 No 1, April 2020 https://japs.ejournal.unri.ac.id/

Aplikasi diperuntukkan secara internal bagi para staf di instansi pemerintahan Selain itu tujuan dari kebijakan e-government adalah untuk mengurangi penggunaan sistem manual atau penggunaan kertas dalam setiap pelayanan. Dengan adanya kebijakan tekhnologi informasi pada lingkungan pemerintah diharapkan terwujudnya egovernment yang transparan dan efesien.

Reformasi birokrasi merupakan suatu gagasan yang dibuat oleh pemerintah untuk mereform tatanan birokrasi mulai dari struktur, fungsi, tugas hingga seluruh pelaksanaan kegiatan pemerintahan salah satunya dalam hal pelayanan. Dalam kajian (Natasurya, 2014) mengatakan bahwa kebijakan e-government pada lingkungan pemerintahan melalui sistem informasi menejemen pegawai dapat diterapkan dengan cukup baik, sistem informasi manajemen pegawai guna penyediaan data-data kepegawaian.

Kebijakan e-government pada penerapan sistem manajemen kepegawaian dapat didukung melalui beberapa komponen yaitu komponen kondisi data dan infrastruktur baik itu institusional, manusia, tekhnologi dan yang terpenting legal yaitu sumber hukum. Dalam kajian (Wahyu, 2012) menurut World Bank Group defenisi egovernment adalah merupakan penggunaan teknologi informasi oleh pemerintah seperti wid area networks, internet, dan computer mobile yang mempunai kemampuan menstranformasikan hubungan dengan rakyat, kelompok bisnis, aparatur pemerintah. (Nia Karniawati \& Romi Rahmadani) dalam penelitiannya mengatakan bahwa untuk mendukung kebijakan sistem informasi manajemen kepegawaian harus dimulai dengan perencanaan. Sistem manajemen kepegawaian merupakan bentuk dari kebijakan egovernment, dimana sebagai pendukung terciptanya database kepegawaian, mulai dari penyimpanan, mengolah, dan mendistribusikan data pegawai untuk mengambil sebuah keputusan pada lingkungan pegawai. Dalam mewujudkan kebijakan e-governmant diutamakan terpenuhinya infrastruktur informasi dan tekhnologi.

Penelitian (Maria Ketty Djawa \& Durinta Puspasari, 2015) menjawab bahwa untuk mendukung kebijakan e-government yaitu sistem informasi manajemen kepegawaian dijalankan oleh sebuah badan atau yang dimaksud dengan badan kepegawaian. Kebijakan sistem manajemen kepegawaian ini bertujuan dalam pengelolaan data kepegawaian, dimana mempermudah penyusunan laporan, validasi, dan sinkronisasi pada data pegawai dengan sistem elektronik atau e-government. Dalam rangka membantu kebijakan pemerintah dalam bidang kepegawaian dan menunjang kinerja dan tata kelola pemerintahan yang baik maka Badan Kepegawaian dan 
Pengembangan Sumber Daya Manusia atau yang disingkat (BKPSDM) memiliki tugas menyelenggarakan urusan penunjangan bidang kepegawaian, pendidikan dan pelatihan.

Penelitian (Wasiah Sufi \& Dwi Herlinda, 2017) juga membahas mengenai sistem aplikasi pelayanan kepegawaian, dimana hasil kajiannya adalah bahwa dalam pelaksanaan kebijakan sistem aplikasi yang berkenaan dengan kepegawaian dilaksanakan oleh badan kepegawaian, pelaksanaan ini untuk mewujudkan kebijakan egovernment. Penggunaan sistem aplikasi pada kepegawaian memiliki beberapa hambatan yaitu ketidak siapan lembaga dalam memanfaatkan dan menggunakan aplikasi sistem kepegawaian. Banyak kebijakan yang dilakukan oleh pemerintah untuk mewujudkan tata kelola pemerintahan atau mereformasi birokrasi, mulai dari lahirnya konsep Good Governance, Reinventing Governance, E-Government dan sebagainya. Semua hal tersebut dilakukan untuk mewujudkan tata kelola pemerintahan yang baik, baik dalam pelayanan kepada masyarakat, kinerja pemerintah dan yang berkaitan dengan fungsi pemerintahan.

Salah satu kebijakan pemerintah dalam mewujudkan e-government adalah dengan keluarnya Undang-Undang Nomor 11 Tahun 2008 Tentang Informasi dan Transaksi Elektronik, bahwa penyelenggaraan sistem elektronik dilaksanakan oleh Penyelenggara negara, Perorangan, Badan Usaha ataupun masyarakat. Badan Kepegawaian dan Pengembangan Sumber Daya Manusia adalah penyelenggara negara yang sengaja dibentuk oleh pemerintah untuk melakukan tugas dan fungsi yaitu mewujudkan tata kelola sumber daya manusia kepegawaian pada instansi pemerintah. Sistem elektronik adalah serangkaian perangkat dan prosedur elektronik yang berfungsi mempersiapkan, mengumpulkan, mengolah, menganalisis, menyimpan, menampilkan, mengumpulkan, mengirim dan menyebarkan informasi elektronik. Dalam (Sri Mulyani \& dkk, 2018) sistem manajemen informasi manajemen merupakan sistem infromasi yang sudah terkomputerisasi yang bekerja karena adanya interaksi manusia dan Komputer.

Penelitian (Yulia Djahir \& Dewi Pratita, 2014) membagi sistem informasi yaitu sistem informasi formal maupun nonformal, baik yang manual maupun yang komputer, termasuk juga sistem informasi proyek, sistem informasi perkantoran, sistem informasi intelejen, sistem informasi peramalan dan bebagai model Komputer yang memproses data dan berbagai sistem informasi. (Arrofik Zulkarnaen \& Anggraini, 2016) menurut penelitiannya sistim IT atau infornasi dan tekhnologi berpengaruh terhadap sistem manajemen kepegawaian selain dari kesadaran pengelolaan terhadap sistem menejemen kepegawaian. Kebijakan e-government penting untuk di evaluasi agar dapat melihat 
Japs: Jurnal Administrasi Politik dan Sosial, Vol. 1 No 1, April 2020

https://japs.ejournal.unri.ac.id/

kondisi pengelolaan IT, menilai penggunaan elektronik sistem manajemen kepegawaian. (Novi Prisma Yunita \& Rudi Dwi Aprianto, 2018) meneliti kondisi penerapan e-government di Indonesia, dalam penelitiannya dinyatakan bahwa intruksi kebijakan e-government di Indonesia diawali dengan terbukanya pintu dari intruksi Presiden yaitu No.3 Tahun 2003 tentang kebijakan dan strategi nasional pengembangan e-government. Pemerintah mengintruksikan kepada pejabat-pejabat daerah seperti Gubernur, Bupati/Walikota untuk mengambil langkah kebijakan e-government.

Dalam rangka merespon intruksi tersebut Walikota Pekanbaru mengeluarkan kebijakan berupa Peraturan Walikota Pekanbaru Nomor 158 Tahun 2019 Tentang Pengelolaan Teknologi Informasi Kepegawaian Daerah, dalam rangka pelaksanaan manajemen kepegawaian yang professional dan berkualitas berbasis tekhnologi informasi. Dalam kebijakan tersebut Walikota Pekanbaru memberikan intruksi kepada Badan Kepegawaian dan Pengembangan Sumber Daya Manusia atau (BKPSDM) sebagai penyelenggara sistem informasi manajemen kepegawaian atau yang disingkat dengan (SIMPEG). Sistem informasi manajemen kepegawaian adalah aplikasi yang memuat modul pengelolaan data kepegawaian.

Berdasarkan Laporan Kinerja Instansi Pemerintah Badan Kepegawaian dan Pengembangan Sumber Daya Manusia (BKSDM) Kota Pekanbaru tahun 2018 terdapat beberapa isu-isu strategis berkenaan dengan penerapan e-government (electronic government) yaitu adanya beberapa aktifitas yang masih menggunakan sistem manual yaitu salah satunya adalah sistem absensi aparatur sispil negara. Kemudian perlu membangun database kepegawaian yang uptodate dan terintegrasi dalam rangka penyelenggaraan manajemen kepegawaian dan pelayanan kepegawaian yang berbasis tekhnologi informasi dan komunikasi. Penyesuaian berbagai regulasi dan kebijakan pembinaan aparatur sipil negara yang belum disesuaikan dengan dinamika perkembangan dan kebutuhan pembinaan aparatur sipil negara dan belum optimalnya pemanfaatan IT atau tekhnologi dan infornasi dalam memberikan pelayanan kepegawaian.

Rumusan masalah dalam penelitian ini adalah : 1). Bagaiaman Penyediaan Sistem Informasi Manajemen Pegawai Pada Badan Kepegawaian Dan Pengembangan Sumber Daya Manusia Kota Pekanbaru Dalam Mendukung Kebijakan E-Government Pada Tahun 2019? Dan 2). Apa yang menjadi Faktor Pendukung Penyediaan Sistem Informasi Manajemen Pegawai Pada Badan Kepegawaian Dan Pengembangan Sumber Daya Manusia Kota Pekanbaru Dalam Mendukung Kebijakan E-Government Pada Tahun 2019? 
Japs: Jurnal Administrasi Politik dan Sosial, Vol. 1 No 1, April 2020 https://japs.ejournal.unri.ac.id/

Adapun tujuan dari penelitian ini adalah : 1). Untuk mengetahui Penyediaan Sistem Informasi Manajemen Pegawai Pada Badan Kepegawaian Dan Pengembangan Sumber Daya Manusia Kota Pekanbaru Dalam Mendukung Kebijakan E-Government Pada Tahun 2019 dan 2.) Untuk mengetahui Faktor Pendukung Penyediaan Sistem Informasi Manajemen Pegawai Pada Badan Kepegawaian Dan Pengembangan Sumber Daya Manusia Kota Pekanbaru Dalam Mendukung Kebijakan E-Government Pada Tahun 2019.

\section{METODE PENELITIAN}

Metode penelitian yang digunakan adalah pendekatan kualitatif. Dimana penelitian kualitatif adalah penelitian yang menekankan pada kata-kata dan mengumpulkan informasi secara terperinci. Dalam penelitian ini penulis menggunkan penilitian kualitatif deskriptif dimana bertujuan menggambarkan sifat-sifat suatu individu, keadaan, gejala, atau kelompok tertentu, penelitian deskriptif dapat dilakukan di laboratorium/pustaka atau dilapangan. Jenis penelitian ini adalah studi literature dimana sumber data diperoleh dari produk hukum, artikel jurnal, dokumen terkait dan sumber media massa. Lokasi penelitian adalah. Badan Kepegawaian dan Pengembangan Sumber Daya Manusia Kota Pekanbaru. Teknik pengumpulan data yaitu dokumentasi.

\section{HASIL DAN PEMBAHASAN}

\section{Penyediaan Sistem Informasi Manajemen Pegawai Pada Badan Kepegawaian}

Dan Pengembangan Sumber Daya Manusia Kota Pekanbaru Pada Tahun 2019.

Kedudukan, tugas dan fungsi Badan Kepegawaian dan Pengembangan Sumber Daya Manusia Kota Pekanbaru dibentuk berdasarkan Peraturan Daerah Kota Pekanbaru Nomor 9 Tahun 2016 tentang pembentukan dan susunan perangkat daerah kota pekanbaru yang memiliki tugas menyelenggarakan urusan penunjang bidang kepegawaian, pendidikan dan pelatihan. Badan Kepegawaian dan Sumber Daya Manusia Kota Pekanbaru berkomitmen untuk melaksanakan pengelolaan sumber daya kepegawaian dan manajemen pengembangan sumber daya manusia secara strategis. BKPSDM merupakan badan yang melaksanakan terkait dengan peningkatan reformasi birokrasi khususnya dilingkungan Pemerintahan Daerah Kota Pekanbaru. 


\section{Gambar 1. Transformasi Birokrasi}

2093

Q018

2025

dynamic

Manajemerovernance

Administrasi

Kepegawaia

$\mathrm{n}$

Sumber Data : Renstra BKPSDM 2017-2022

Badan Kepegawaian dan Pengembangan Sumber Daya Manusia melaksanakan sebuah program yang tujuannya yaitu untuk meningkatkan kualitas kepegawaian dan tata kelola pemerintahan yang baik. program-program tersebut merupakan komitmen untuk menjawab tantangan kebutuhan masyarakat yang semakin meningkat, terutama dalam hal pelayanan. Untuk mejalankan pelayanan yang baik maka dibutuhkan tata kelola pemerintahan yang baik yaitu bermutu, profesional dan berintegritas. Sistem Informasi Manajemen Pegawai atau program SIMPEG merupakan program dalam rangka mengembangkan Sumber Daya Manusia Aparatur Sipil Negara.

Aplikasi SIMPEG atau Sistem Informasi Manajemen Pegawai merupakan program dari BKPSDM Kota Pekanbaru pada tahun 2019. Situs SIMPEG merupakan pengelolaan data Aparatur Sipil Negara Kota Pekanbaru. Program ini dalam rangka penyempurnaan untuk tercapainya pelayanan yang optimal bagi seluruh ASN dan pemangku kebijakan di kota pekanbaru (Simpeg.Pekanbaru.go.id.).

Tabel 1. Program SIMPEG Kota Pekanbaru

\begin{tabular}{lll}
\hline No. & Nama Unit & Tujuan \\
\hline 01. & SITAWA & Pemberharuan data kepegawaian. \\
\hline 02. & SIPENSI & Pengajuan proses pensiun pegawai. \\
\hline 03. & SICUTI & pengajuan izin cuti pegawai. \\
\hline 04. & SEPAKAT & pengajuan kenaikan pangkat pegawai. \\
\hline 05. & SIJALA & Memperbaharui data keuangan kepegawaian. \\
\hline 06. & E-TAKAH & Tata naskah dalam pemerintahan kota pekanbaru. \\
\hline 07. & SEPJAR & pengajuan izin belajar pegawai. \\
\hline 08. & SITALA & pengurusan penerimaan penghargaan stya lencana pegawai. \\
\hline 09. & E-LEARNING & $\begin{array}{l}\text { Menyediakan berbagai macam literature yang didapat dari } \\
\text { pelatihan-pelatihan.. }\end{array}$ \\
\hline 10. & FAQ & $\begin{array}{l}\text { Menyediakan informasi dari pertanyaan yang sering dilakukan oleh } \\
\text { pegawai. }\end{array}$ \\
\hline 11. & SCAN QR & Data-data yang dilihat dengan menggunakan alat pendeteksi. \\
\hline Cumber Data: BKPSDM Kota Pekanbaru,2019
\end{tabular}


Berdasarkan tabel 1. diatas bahwa program sistem informasi menejemen pegawai merupakan komitmen dari pemeintahan kota pekanbaru dalam rangka mewujudkan e- government melalui badan kepegawaian dan pengembangan sumber daya manusia.

\section{Gambar 2. Aplikasi SIMPEG Kota Pekanbaru}

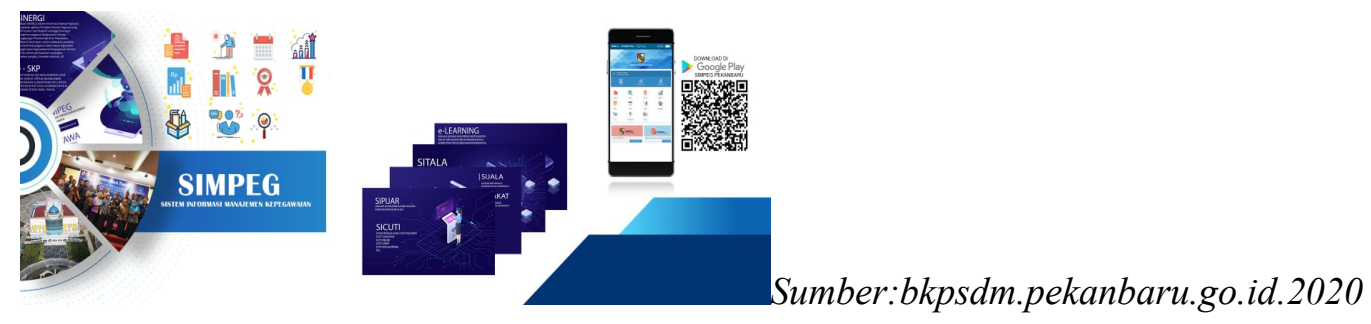

Gambar 2. Merupakan bentuk aplikasi sistem informasi manajemen pegawai yang disediakan oleh badan kepegawaian dan pengembangan sumber daya manusia. Dalam penggunaan aplikasi sistem informasi manajemen pegawai, aparatur sipil negara dapat mengaksesnya dalam bentuk aplikasi smartphone maupaun dalam bentuk login akun pada simpeg.kota.pekanbaru.go.id melalui aplikasi google crom.

\section{Gambar 3. Login Akun Simpeg Kota Pekanbaru}

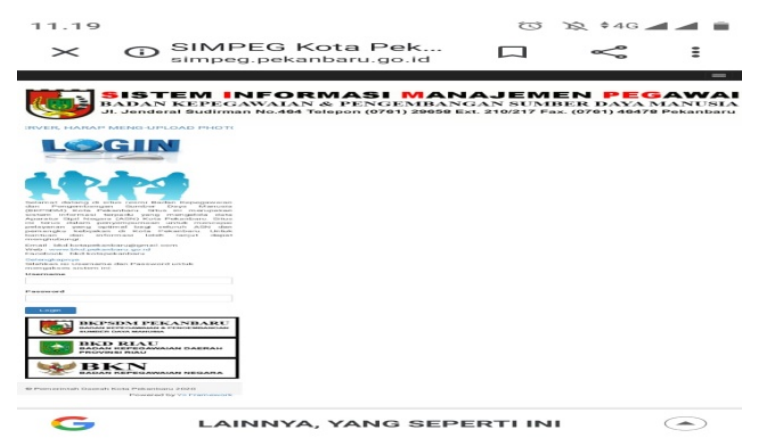

Sumber:SIMPEG.Pekanbaru.go.id,2019

Gambar 3. Menunjukkan bahwa aplikasi sistem informasi manajemen pegawai dapat diakses melalui plogin sistem informasi manajemen pegawai secara langsung melalui akun google.chrome. Sehingga memudahkan aparatur sipil negara untuk mengakses dan mempergunakan aplikasi sistem informasi manajemen pegawai untuk kepentingan kepegawaian.

Adapun alur dalam pengunaan aplikasi sistem informasi manajemen kepegawaian adalah sebagai berikut: 


\section{Bagan 1. Alur Login Aplikasi SIMPEG}

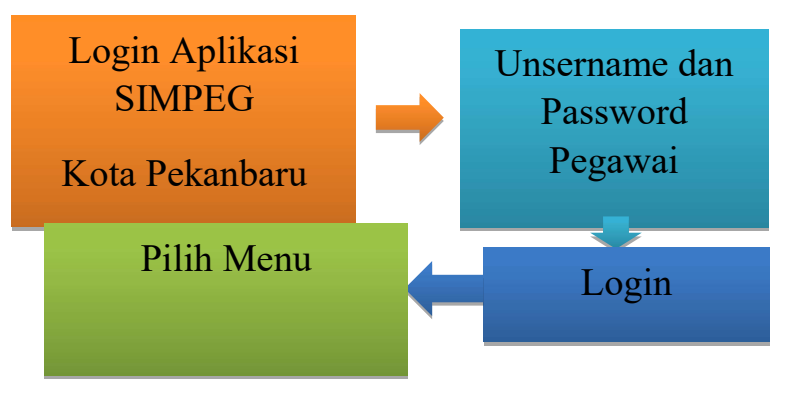

Sumber: Olahan Penulis,2020

Berdasarkan bagan 1 diatas bahwa dalam penggunaan aplikasi sistem informasi manajemen pegawai pada aparatur kota pekanbaru yaitu dengan menggunakan username dan password yang telah terdaftar pada Badan Kepegawaian dan Pengembangan Sumber Daya Manusia atau telah terdaftar pada Dinas Komunikasi dan Informasi Kota Pekanbaru. Tujuannya adalah sebagai pengamanan data-data kepegawaian yang telah terdata dalam aplikasi sistem informasi manajemen pegawai. Kemudian setelah melakukan username dan password maka pegawai yang ingin menggunakan aplikasi atau ingin menginput data melakukan login aplikasi untuk masuk kedalam sistem menu yang disediakan oleh Badan Kepegawaian dan Pengembangan Sumber Daya Manusia. Setelah melakukan login maka pegawai dapat memilih menu yang ingin digunakan.

Tujuan dari adanya aplikasi atau program sistem informasi manajemen pegawai yang dilaksanakan oleh Badan Kepegawaian dan Pengembangan Sumber Daya Manusia adalah selain mewujudkan pemerintah yang berbasis e-government juga mendukung kebijakan Kepala Daerah yaitu Walikota Pekanbaru dan mendukung visi Walikota Pekanbaru yaitu “Terwujudnya Pekanbaru Sebagai Smart City Yang Madani”.

\section{Faktor Pendukung Penyediaan Sistem Informasi Manajemen Pegawai Pada Badan Kepegawaian Dan Pengembangan Sumber Daya Manusia Kota Pekanbaru Dalam Mendukung Pada Tahun 2019.}

Dalam rangka mewujudkan e-government pada lingkungan pemerintahan kota pekanbaru ada beberapa faktor pendukung yang mesti diperhatikan, salah satunya dalam penyediaan aplikasi sistem informasi manajemen pegawaian pada Badan Kepegawaian dan Pengembangan Sumber Daya Manusia yang bertujuan untuk mewujudkan pemerintahan yang cerdas data dan cerdas tekhnologi. Selain itu aplikasi sistem 
informasi manajemen pegawai juga memiliki tujuan yaitu mempermudah pegawai untuk memperbaharui data-data berkenaan dengan kepegawaian dilingkungan pemerintahan Kota Pekanbaru.

Ada beberapa faktor pendukung dalam penyediaan aplikasi sistem informasi manajemen pegawai pada Badan Kepegawaian dan Pengembangan Sumber Daya Manusia Kota Pekanbaru antara lain:

1. Adanya Faktor jaminan Hukum sebagai kebijakan aplikasi sistem informasi manajemen pegawai melalui Peraturan Walikota Pekanbaru Nomor 158 Tahun 2019 Tentang Pengelolaan Teknologi Informasi Kepegawaian Daerah.

2. Adanya dukungan yang tercantum dalam Rencana Strategis Badan Kepegawaian Dan Pengembangan Sumber Daya Manusia Tahun 2017-2022 mengenai visi Walikota Pekanbaru yaitu mewujudkan Kota Pekanbaru sebagai Smart City. Dan tercantumnya pada program dan kegiatan utama Badan Kepegawaian dan Pengembangan Sumber Daya Manusia yaitu pengembangan informasi kepegawaian daerah dan peningkatan kapasitas aparatur bagian pelayanan dan penerapan e-government.

3. Adanya dukungan anggaran sebagai penyediaan sarana dan prasarana bagi pelaksanaan sistem informasi manajemen pegawai tercantum pada Laporan Kinerja Instansi pada Badan Kepegawaian dan Pengembangan Sumber Daya Manusia. 
Tabel.2 Efesiensi Anggaran BKPSDM Kota Pekanbaru Tahun 2018

\begin{tabular}{|c|c|c|c|c|c|}
\hline No. & Uraian & $\begin{array}{l}\text { Anggaran } \\
\text { (Rp) }\end{array}$ & $\begin{array}{c}\text { Realisasi } \\
\text { (Rp) }\end{array}$ & $\begin{array}{c}\text { Capaian } \\
\%\end{array}$ & $\begin{array}{c}\text { Efesiensi } \\
\%\end{array}$ \\
\hline 01. & $\begin{array}{l}\text { Program Pelayanan } \\
\text { Adminsitrasi } \\
\text { Perkantoran }\end{array}$ & 2.881 .233 .948 & 2.619 .143 .557 & 90.90 & 9.1 \\
\hline 02. & $\begin{array}{l}\text { Program Peningkatan } \\
\text { Sarana Dan Prasarana } \\
\text { Aparatur }\end{array}$ & 38.440 .300 & 34.600 .000 & 90.1 & 9.99 \\
\hline 03. & $\begin{array}{l}\text { Program Fasilitas } \\
\text { Pindah/Purna Tugas } \\
\text { Pns }\end{array}$ & - & - & - & - \\
\hline 04. & $\begin{array}{l}\text { Program Peningkatan } \\
\text { Kapasitas Sumber } \\
\text { Daya Aparatur }\end{array}$ & 182.750 .000 & 138.219 .354 & 75.63 & 24.37 \\
\hline 05. & $\begin{array}{l}\text { Program Peningkatan } \\
\text { Pengembangan } \\
\text { Sistem Laporan } \\
\text { Capaian }\end{array}$ & 6.885 .500 & 6.885 .500 & 100 & 100 \\
\hline 06. & $\begin{array}{l}\text { Program Pendidikan } \\
\text { Kedinasan }\end{array}$ & 100.340 .650 & 83.795 .050 & 83.51 & 16.49 \\
\hline 07. & $\begin{array}{l}\text { Program Peningkatan } \\
\text { Kapasitas Sumber } \\
\text { Daya Aparatur }\end{array}$ & 1.448 .469 .500 & 1.436 .788 .400 & 99.19 & 0.81 \\
\hline 08. & $\begin{array}{l}\text { Program Pembinaan } \\
\text { Dan Pengembangan } \\
\text { Aparatur }\end{array}$ & 1.637 .448 .765 & 863.697 .607 & 52.75 & 47.25 \\
\hline 09 & $\begin{array}{l}\text { Program Peningkatan } \\
\text { Pelayanan Sosial } \\
\text { Profesi ASN }\end{array}$ & 22.759 .700 & 7.985 .00 & 35.08 & 64.92 \\
\hline & Jumlah & 6.776 .928 .363 & 5.308 .458 .968 & 78.33 & 21.67 \\
\hline
\end{tabular}

Sumber Data: Laporan Kinerja Instansi Pemerintahan Badan Kepegawaian dan Pengembangan Sumber Daya Manusia Kota Pekanbaru,2018.

Berdasarakn data tabel 2 diatas bahwa dalam mendukung program sistem informasi manajemen pegawai pada Badan Kepegawaian dan Pengembangan Sumber Daya Manusia Kota Pekanbaru dalam rangka mendukung kebijkan e-government maka perlu adanya dukungan anggaran sebagai pendukung fasilitas sarana dan prasarana. Dari bebrapa faktor pendukung tersebut merupakan kebijakan yang sangaja dibuat baik itu pihak pemerintah yaitu Walikota Pekanbaru maupuan pihak penyelenggara yaitu Badan Kepegawaian dan Pengembangan Sumber Daya Manusia dalam bentuk Aplikasi Sistem Informasi Manajemen Pegawai di lingkungan instansi Pemerintah Kota Pekanbaru tahun 2019. 


\section{KESIMPULAN}

Adapun kesimpulan dari uraian pembahasan diatas antara lain adalah:

1. Tujuan dari adanya aplikasi atau program sistem informasi manajemen pegawai yang dilaksanakan oleh Badan Kepegawaian dan Pengembangan Sumber Daya Manusia adalah selain mewujudkan pemerintah yang berbasis e-government juga mendukung kebijakan Kepala Daerah yaitu Walikota Pekanbaru dan mendukung visi Walikota Pekanbaru yaitu "Terwujudnya Pekanbaru Sebagai Smart City Yang Madani”. Selain itu Aplikasi SIMPEG atau Sistem Informasi Manajemen Pegawai merupakan program dari BKPSDM Kota Pekanbaru pada tahun 2019. Situs SIMPEG merupakan pengelolaan data Aparatur Sipil Negara Kota Pekanbaru. Program ini dalam rangka tercapainya pelayanan yang optimal bagi seluruh ASN.

2. Adapun faktor pendukung e-government dalam penyediaan aplikasi sistem informasi manajemen pegawai pada Badan Kepegawaian dan Pengembangan Sumber Daya Manusia Kota Pekanbaru adalah: Peraturan Walikota Pekanbaru Nomor 158 Tahun 2019 Tentang Pengelolaan Teknologi Informasi Kepegawaian Daerah; Rencana Strategis Badan Kepegawaian Dan Pengembangan Sumber Daya Manusia Tahun 2017-2022 mengenai visi Walikota Pekanbaru yaitu mewujudkan Kota Pekanbaru sebagai Smart City dan Anggaran pada Badan Kepegawaian dan Pengembangan Sumber Daya Manusia Kota Pekanbaru.

\section{DAFTAR PUSTAKA}

Agustino, L. (2016). Dasar-Dasar Kebijakan Publik. Bandung: ALFABET.

Arrofik Zulkarnaen, \& Anggraini. (2016). Evaluasi Sistem Informasi Manajemen Kepegawaian (SIMPEG) Menggunakan Framework Cobit 4.1 (Studi Kasus: Kementerian Agama Kantor Kota Pekanbaru). Jurnal Rekayasa Dan Menejemen Sistem Informasi, II(2).

Haryono. (2017). Kebijakan Sistem Aplikasi Pelayanan Kepegawaian On-Line Untuk Mewujudkan E-Government Di Pemerintah Kabupaten Karangan (Studi Kasus Di Pemerintah Kabupaten Karanganyar). Pasca Sarjana Hukum, V(1).

Maria Ketty Djawa, \& Durinta Puspasari. (2015). Implementasi Aplikasi Sistem Informasi Manajemen Kepegawaian (SIMPEG) Untuk Mendukung EGovernment Pada Badan Kepegawaian Daerah (BKD) Provinsi Jawa Timur. Pendidikan Ekonomi. 
Natasurya, R. (2014). Penerapan Kebijakan E-Government Melalui Sistem Informasi Manajemen Kepegawaian (SIMPEG) Di Badan Kepegawaian Daerah (BKD) Provinsi Kalimantan Timur. Ilmu Pemerintahan, II(1).

Nia Karniawati, \& Romi Rahmadani. (n.d.). Analisis Kebijakan Penerapan EGovernment Melalui Sistem Informasi Manajemen Kepegawaian (SIMPEG) (Suatu Studi Pada Biro Kepegawaian Sekretariat Daerah Provinsi Jawa Barat). Majalah Ilmiah UNIKOM, VII(2).

Novi Prisma Yunita, \& Rudi Dwi Aprianto. (2018). Kondisi Terkini Perkembangan Pelaksanaan E-Government Di Indonesia : Analisis Website. Seminar Nasional Tekhnologi Informasi dan Komunikasi.

Richardus Eko Indrajit, Dudy Rudianto, \& Akbar Zainuddin. (2005). e-Government In Action Ragam Kasus Implementasi Sukses Di Berbagai Belahan Dunia. Yogyakarta: Andi Yogyakarta.

Simpeg.Pekanbaru.go.id. (n.d.). SIMPEG Kota Pekanbaru. Retrieved Desember 13, 2019, from (https://simpeg.pekanbaru.go.id)

Sore. B, Unddin, \& Sobirin. (2017). Kebijakan Publik. Makassar: CV SAH MEDIA.

Sri Mulyani, \& dkk. (2018). Sistem Informasi Akuntasi Aplikasi Di Sektor Publik. Bandung: UNPAD PRESS.

Vita Elysa, \& dkk. (2017). Implementasi E-Government Untuk Mendorong Pelayanan Publik Yang Terintegrasi Di Indonesia. Tangerang Selatan: Universitas Terbuka (repository.ut.ac.id).

Wahyu, K. d. (2012). Implememtasi E-Government System Dalam Upaya Peningkatan Clean And Good Governance Di Indonesia. Xi(1).

Wasiah Sufi, \& Dwi Herlinda. (2017). Penerapan Sistem Aplikasi Pelayanan Kepegawaian (SAPK) Berbasis Online Pada Badan Kepegawaian Daerah Kota Pekanbaru. Niara, IX(2).

Yudho Giri Suhcayo, \& dkk. (2013). Kerangka Kerja Interoperabilitas E-Government Indonesia. Jakarta: Kementerian Komunikasi Dan Informatika (http://www.aptika.kominfo.go.id).

Yulia Djahir, \& Dewi Pratita. (2014). Bahan Ajar Sistem Informasi Manajemen. Yogyakarta: deepublish.

\section{Dokumen:}

Undang-Undang Nomor 11 Tahun 2008 Tentang Informasi dan Transaksi Elektronik.

Peraturan Walikota Pekanbaru Nomor 158 Tahun 2019 Tentang Tentang Pengelolaan Teknologi Informasi Kepegawaian Daerah. 
Rencana Strategis Badan Kepegawaian dan Pengembangan Sumber Daya Manusia Kota Pekanbaru Tahun 2017-2022.

Laporan Kinerja Instansi Pemerintahan Badan Kepegawaian dan Pengembangan Sumber Daya Manusia Kota Pekanbaru Tahun 2018. 